\section{Molecular diagnostic testing}

To the Editor: I read with interest the article by Xue et al. in the June 2015 issue of Genetics in Medicine. ${ }^{1}$ I am concerned about an omission in the molecular genetic testing algorithm (Figure 1 in the article).

The authors mention performing chromosomal microarray testing and fragile $\mathrm{X}$ testing in cases of autism and intellectual disability before proceeding to exome sequencing. Fragile $\mathrm{X}$ testing is not shown in the algorithm for testing-this is a significant omission. Because algorithms are often used after articles have been published and have a life of their own in the hands of clinicians and third-party payers, I would ask that the algorithm be amended to correct this error. I further submit that autism and intellectual disability should not be "coupled" as a precondition for this testing. Microarray testing and fragile $\mathrm{X}$ analysis are appropriate in the presence of autism or intellectual disability. Intellectual disability is difficult to diagnose early in life, so significant (global) developmental delay should

\section{Response to Saul}

To the Editor: We understand the concern raised by Dr Saul ${ }^{1}$ that a fragile $\mathrm{X}$ analysis is not included along with a microarray in the testing algorithm for the categories of "multiple nonspecific concerns," "autism and intellectual disability," and "no gene panel available" (Figure 1) of our recent publication. ${ }^{2}$ The algorithm refers to clinical problems in addition to intellectual disability and autism. Fragile $\mathrm{X}$ testing is discussed twice in the text as first-tier molecular testing for autism and intellectual disability. Furthermore, in Figure 1, suspicion of a triplet-repeat disorder (such as fragile $\mathrm{X}$ ) should prompt a triplet-repeat analysis. Our article was intended to inform clinicians on how to select from among the often confusing variety of available molecular testing options. The algorithm is not presented as a formal guideline. Other papers, including a guideline from the American College of Medical Genetics and Genomics, are more comprehensive and appropriate for specific clinic problems such as intellectual disability and autism. ${ }^{3,4}$ be used as a standard for this genetic testing in the pediatric population. $^{2}$

\section{DISCLOSURE}

The author declares no conflict of interest.

\section{Robert A. Saul, $M D^{1,2}$}

${ }^{1}$ General Pediatrics, Children's Hospital, Greenville Health System, Greenville, South Carolina, USA; ${ }^{2}$ University of South Carolina School of Medicine, Greenville, South Carolina, USA. Correspondence: Robert A. Saul (rsaul@ghs.org)

\section{REFERENCES}

1. Xue Y, Ankala A, Wilcox WR, Hegde MR. Solving the molecular diagnostic testing conundrum for Mendelian disorders in the era of next-generation sequencing: single-gene, gene panel, or exome/genome sequencing. Genet Med 2015; 17:444-451.

2. Moeschler JB, Shevell M; Committee on Genetics. Comprehensive evaluation of the child with intellectual disability or global developmental delays. Pediatrics 2014;134:e903-e918.

doi:10.1038/gim.2015.115

\section{DISCLOSURE}

Y.X., A.A., and M.R.H. work for a nonprofit diagnostic laboratory. W.R.W. declares no conflict of interest.

Yuan Xue, PhD, FACMG ${ }^{1}$, Arunkanth Ankala, $P h D^{1}$, William R. Wilcox, $M D, P h D^{2}$ and Madhuri R. Hegde, PhD, FACMG ${ }^{1}$

${ }^{1}$ Emory Genetics Laboratory, Department of Human Genetics, Emory University Schoo of Medicine, Atlanta, Georgia, USA; ${ }^{2}$ Clinic division, Department of Human Genetics, Emory University School of Medicine, Atlanta, Georgia, USA. Correspondence:

YuanXue (yuan.xue@emory.edu)

\section{REFERENCES}

1. Saul RA. Molecular genetic testing. Genet Med 2015;17:761.

2. Xue Y, Ankala A, Wilcox WR, Hegde MR. Solving the molecular diagnostic testing conundrum for Mendelian disorders in the era of next-generation sequencing: single-gene, gene panel, or exome/genome sequencing. Genet Med 2015;17:444-451.

3. Moeschler JB, Shevell M; Committee on Genetics of the American Academy of Pediatrics. Comprehensive evaluation of the child with intellectual disability or global developmental delays. Pediatrics 2014;134:e903-e918.

4. Schaefer GB, Mendelsohn NJ; Professional Practice and Guidelines Committee. Clinical genetics evaluation in identifying the etiology of autism spectrum disorders: 2013 guideline revisions. Genet Med 2013;15:399-407.

doi:10.1038/gim.2015.114 